\title{
Penggantian Bungkil Kelapa dengan Lumpur Sawit Fermentasi dalam Ransum Terhadap Kecernaan Kelinci Lokal Jantan
}

\author{
Duta Setiawan ${ }^{1}$, Marjoko Purnomosidi $^{2}$ \\ 1,2 Program Studi Peternakan, Fakultas Pertanian, Universitas Tanjungpura Kota \\ Pontianak, Kalimantan Barat \\ 1Email: duta.setiawan@faperta.untan.ac.id
}

\begin{abstract}
The aim of this research was to determine the effect of substitution coconut meal (CM) with fermented solid (FS) in the ration on the performance of local male rabbit. This research had been carried out at teaching farm Faculty of Agriculture, Tanjungpura University and Animal Nutrition Laboratory, Department of Animal Husbandry and Veterinery West Kalimantan Province. The 16 heads of rabbit were during 8 weeks. This research used Completely Randomized Design one way classification with four treatments $(P 0, P 1, P 2, P 3)$, and four replications and each replication used one local male rabbit. The treatments of ration were: $P 0=60 \%$ Field Grass (FG) $+40 \%$ concentrate $(15 \% \mathrm{CM}+0 \% \mathrm{FS}) ; P 1=60 \% \mathrm{FG}+40 \%$ concentrate $(10 \% \mathrm{CM}+5 \%$ FS); $P 2=60 \% F G+40 \%$ concentrate $(5 \% C M+10 \% F S)$ and $P 3=60 \% F G+40 \%$ concentrate $(0 \% \mathrm{CM}+15 \% \mathrm{FS})$, repectively. The observed variables were average daily gain, feed consumption, feed convertion and feed cost per gain. The result showed that the feed consumption 36,64 - 42,36 g/day, average daily gain 6,87 - 7,31 g/day, dry matter digestibility 49,80 - 53,31\%, and organic matter digestibility 42,66 $49,35 \%$. It conclude that the substitution of coconut meal with FS up to $100 \%$ (15\% from total ration) have no significant effect on performance of local male rabbit, but at $15 \%$ from total ration of substitution $(P 3)$ could reduce feed cost per gain value.

Keywords: local male rabbit, fermented solid, coconut meal, digesbility.
\end{abstract}

\begin{abstract}
ABSTRAK
Tujuan dari penelitian ini adalah untuk mengetahui pengaruh substitusi tepung kelapa (CM) dengan fermentasi padat (FS) dalam ransum terhadap kinerja kelinci jantan lokal. Penelitian ini dilakukan di peternakan percontohan Fakultas Pertanian, Universitas Tanjungpura dan Laboratorium Nutrisi Ternak, Dinas Peternakan dan Kesehatan Hewan Pemerintah Kalimantan Barat. Penelitian ini dilaksanakan selama 8 minggu menggunakan 16 kelinci. Penelitian ini menggunakan Rancangan Acak Lengkap dengan empat perlakuan (P0, P1, P2, P3), dan empat ulangan dan masing masing berisi satu kelinci jantan lokal. Perlakuan yang diberikan adalah substitusi CM dengan FS, yaitu: $P 0=60 \%$ Field Grass (FG) + konsentrat $40 \%(15 \% \mathrm{CM}+0 \% \mathrm{FS})$; $\mathrm{P} 1=60 \%$ konsentrat $\mathrm{FG}+40 \%$ (FS $10 \%+5 \% \mathrm{FS}$ ); P2 $=60 \%$ konsentrat $\mathrm{FG}+40 \%$ $(5 \% \mathrm{CM}+10 \% \mathrm{FS})$ dan konsentrat $\mathrm{P3}=60 \% \mathrm{FG}+40 \%$ (FS 0\% + 15\% FS). Parameter yang diambil adalah kenaikan harian rata-rata, konsumsi pakan, konversi pakan dan biaya pakan per perolehan. Hasil penelitian ini adalah konsumsi pakan $36,64-42,36 \mathrm{~g} /$ hari, rata - rata kenaikan harian 6,87 - 7,31 g / hari, kecernaan bahan kering 49,80 - 53,31\%, dan kecernaan bahan organik 42,66 - 49,35\%. Hasil penelitian menunjukkan bahwa substitusi tepung kelapa dengan FS sampai $100 \%$ (15\% dari total ransum) tidak berpengaruh signifikan terhadap kinerja kelinci jantan lokal, namun sebesar $15 \%$ dari total ransum substitusi (P3) dapat menekan biaya makan per perolehan nilai.
\end{abstract}

Kata kunci: kelinci jantan lokal, padatan fermentasi, tepung kelapa, kecernaan

\section{Pendahuluan}

Ternak kelinci adalah salah satu komoditas penting yang menjadi tren makanan masyarakat dan dapat menghasilkan daging berkualitas tinggi dengan kandungan protein hewani yang tinggi pula. Kelinci menghasilkan daging yang memiliki nilai protein hewani 
berkualitas yang dapat dijadikan alternatif dalam pemenuhan gizi masyarakat. Kebutuhan protein hewani semakin meningkat di masyarakat, hal ini sejalan dengan peningkatan jumlah penduduk. Peningkatan kebutuhan perlu dicarikan pemecahan melalui peningkatan produksi peternakan, penganekaragaman produk dan pencarian sumber protein hewani baru.

Daging kelinci tidak kalah menarik nilai nutrisinya dengan daging ternak lainnya, yaitu memiliki kandungan protein sebesar $\pm 20 \%$, rasanya enak, tidak diharamkan agama, dan kandungan lemaknya rendah. Selain itu dapat dikembangkan dalam bentuk perusahaan skala besar untuk komersial. Kandungan kolesterolnya juga rendah yaitu $1,39 \mathrm{mg} / \mathrm{kg}$ (Sudaryanto, 2007). Keunggulan ternak kelinci adalah tidak membutuhkan areal yang luas dalam pemeliharaannya, dapat memanfaatkan bahan pakan dari berbagai jenis hijauan, sisa dapur dan hasil sampingan produk pertanian dan hasil sampingannya (kulit/bulu, kepala, kaki, ekor serta kotorannya) dapat dimanfaatkan untuk berbagai keperluan, biaya produksi relatif murah, tidak menuntut modal dalam jumlah besar, pemeliharaannya mudah serta dapat melahirkan anak 4-6 kali setiap tahunnya dan menghasilkan 4-12 anak setiap kelahiran (Damron, 2006).

Kelinci termasuk jenis ternak pseudoruminant, yaitu herbivora yang tidak dapat mencerna serat secara baik (Gidenne et al, 2010),. Fermentasi hanya terjadi di Caecum yang merupakan 50\% dari seluruh kapasitas saluran pencernaan, walaupun memiliki caecum yang besar, kelinci tidak mampu mencerna bahan-bahan organik dan serat kasar dari hijauan sebanyak yang dapat dicerna oleh ruminansia murni. Daya cerna kelinci dalam mengkonsumsi hijauan hanya $10 \%$.

Di Kalimantan Barat pakan komersial ternak kelinci yang ada di pasaran relatif mahal sehingga diperlukan alternatif untuk mencari pakan yang tersedia kontinyu, murah, mudah didapat, memliki nilai gizi yang cukup dan tidak mengganggu kesehatan ternak. Bungkil kelapa sebagai salah satu penyusun konsentrat merupakan bahan pakan sumber protein dalam ransum. Memiliki beberapa kekurangan diantaranya adalah ketersediaannya terbatas dipasaran serta harganya yang relatif mahal. Salah satu alternatif pakan untuk menurunkan harga pakan komersial adalah lumpur sawit fermentasi. Pemanfaatan limbah sebagai pakan ternak juga merupakan salah satu cara pemecahan masalah dalam mengurangi pencemaran lingkungan akibat limbah industri. Peningkatan daya cerna kelinci akan mengoptimalkan pemberian pakan sehingga pakan yang diberikan sesuai dengan kebutuhan dan nutrien yang terkandung di dalamnya akan tercerna dan dimanfaatkan secara optimal.

Lumpur sawit banyak dibuang di sekitar area pabrik pengolahan sawit maupun di bahu jalan perkebunan sawit. Lumpur sawit merupakan larutan buangan yang dihasilkan selama proses pemerasan dan ekstraksi minyak yang terdiri dari $4-5 \%$ padatan, $0,5-1$ 
$\%$ sisa minyak dan sebagian besar air yaitu sebesar $94 \%$. Untuk setiap ton hasil minyak sawit dihasilkan sekitar $2-3$ ton lumpur sawit (Direktorat Jenderal Perkebunan, 2012). Kandungan zat gizi lumpur sawit adalah: protein kasar 12,17 \%, serat kasar 21,15\%, lemak 19,96 \%, selulosa $11,42 \%$, hemiselulosa $18,77 \%$ dan lignin 36,40 \% (Lekito, 2002).

Upaya menurunkan kandungan serat kasar terutama kandungan lignin dan selulosa adalah dengan cara memanfaatkan aktivitas mikroba melalui proses fermentasi. Lumpur Sawit (Solid) merupakan salah satu limbah pengolahan sawit dari sejumlah pabrik pengolahan sawit. Menurut Hidayat et al., (2007) Solid merupakan sumber daya yang cukup potensial sebagai pakan ternak, murah, tersedia dalam jumlah besar dan relatif tersedia sepanjang waktu. Penelitian ini bertujuan untuk mengetahui pengaruh penggunaan lumpur sawit fermentasi untuk mengganti bungkil kelapa dalam Ransum terhadap kecernaan ternak kelinci lokal lepas sapih.

\section{$2 \quad$ Materi dan Metode}

\subsection{Materi Penelitian}

Lumpur sawit fermentasi menggantikan bungkil kelapa dalam ransum ini menggunakan ternak kelinci lokal sebanyak 16 ekor berumur 2 bulan dengan bobot ratarata 630 gram. Peralatan yang digunakan antara lain kandang baterai berukuran $50 \times 30 \times 30 \mathrm{~cm}^{3}$. Penyusun ransum dalam penelitian menggunakan rumput lapang, konsentrat menggunakan lumpur sawit fermentasi, jagung, bungkil kelapa, dedak padi, tepung ikan, tepung tapioka dan kalsit.

\subsection{Metode Penelitian}

Hewan ternak kelinci yang digunakan sebanyak dua puluh ekor kelinci dibagi menjadi 4 perlsakuan, 4 ulangan dan masing-masing perlakuan akan mendapatkan 4 perlakuan ransum secara acak, keempat perlakuan ransum tersebut adalah: $\mathrm{P} 0=60 \%$ $R L+40 \%$ konsentrat (15\% bungkil kelapa $+0 \%$ LSF); P1= 60\% RL $+40 \%$ konsentrat ( $10 \%$ bungkil kelapa $+5 \%$ LSF); P2 $=60 \% \mathrm{RL}+40 \%$ konsentrat $(5 \%$ bungkil kelapa + $10 \%$ LSF); P3 $=60 \%$ RL $+40 \%$ konsentrat (0\% bungkil kelapa $+15 \%$ LSF). Ternak kelinci dipelihara dalam kandang individu selama 3 bulan. Masa adaptasi pakan (preliminary) penelitian ini dua minggu pertama dan pada minggu ketiga sampai minggu ke dua belas dilakukan pengamatan. Pemberian pakan $2.5-3 \%$ dari bobot badan dilakukan dua kali sehari pada pagi hari pukul 07.00-08.00 WIB dan pada sore hari pada pukul 16.00-17.00 WIB. Pakan diberikan dengan cara dicampur antara konsentrat dengan rumput lapang, sedangkan air minum diberikan secara ad libitum. Pakan terlebih dahulu ditimbang 
sebelum diberikan, dan sisa pakan yang tidak terkonsumsi juga ditimbang perhari. Penimbangan bobot badan ternak dilakukan setiap bulan.

Banyak parameter dalam penelitian yang diamati antara lain konsumsi pakan, pertambahan bobot badan, , dan Feed cost per gain. Data yang diperoleh dianalisis dengan Sidik Ragam (ANOVA) dan apabila terdapat perbedaan dilanjutkan dengan uji Duncan (Mattjik dan Sumertajaya, 2002).

\section{Hasil Dan Pembahasan}

\subsection{Konsumsi Pakan}

Rataan konsumsi yang diperoleh selama penelitian untuk masing-masing perlakuan P0, P1, P2 dan P3 berturut-turut yaitu 40,11; 36,64; 37,21; dan 42,36 g/ekor/hari. Hasil Anova menunjukkan bahwa konsumsi pakan berbeda tidak nyata. Rataan hasil penelitian PBB (Pertambahan Bobot Badan) dan konsumsi pakan, pakan kelinci lokal jantan dengan perlakuan pakan penggantian bungkil kelapa dengan lumpur sawit fermentasi dalam ransum seperti pada tabel 1. Hal ini berarti penggantian bungkil kelapa dengan LSF sampai 15\% tidak mempengaruhi konsumsi pakan kelinci lokal jantan.

Pengaruh yang tidak nyata disebabkan karena penggantian bungkil kelapa dengan LSF tidak menambah palatabilitas pakan sehingga pakan perlakuan memiliki palatabilitas yang relatif sama. Hal ini diperkirakan karena secara fisik lumpur sawit fermentasi yang digunakan mempunyai tekstur yang halus dan tidak begitu beraroma sehingga setelah bercampur dengan bahan konsentrat lain akan menyatu dengan bau dan tekstur yang sama dengan pakan yang tanpa lumpur sawit fermentasi (pakan kontrol). Selain itu dari segi kualitasnya lumpur sawit fermentasi mempunyai kandungan TDN yang lebih rendah dari pada bungkil kelapa yaitu sebesar 78,7\%. Tetapi proteinnya sangat rendah. Hal ini mengakibatkan protein LSF masih di bawah protein bungkil kelapa. Karena alasan tersebut maka pakan perlakuan yang menggunakan lumpur sawit ferementasi akan memberikan tingkat palatabilitas yang sama dengan pakan kontrol. Salah satu faktor yang mempengaruhi tingkat konsumsi pakan adalah palatabilitas. de Blas et al. (2010) mengatakan bahwa palatabilitas pakan dicerminkan oleh organoleptiknya seperti kenampakan, bau, rasa, dan teksturnya.

Kisaran persentase konsumsi bahan kering yaitu antara 2,2-2,4\% dari bobot badan. Nilai ini masih dalam kisaran standar konsumsi bahan kering kelinci yaitu antara 2,2\% sampai $4 \%$ dari bobot badan (NRC, 1994). Tingkat konsumsi pakan dipengaruhi oleh kualitas ransum yang dapat dilihat dari kandungan nutriennya. Menurut Tazzoli et al. (2009), bahwa tinggi rendahnya kandungan energi dalam pakan berpengaruh terhadap banyak sedikitnya konsumsi pakan. Kandungan Total Digestible 
Nutrien (TDN) lumpur sawit fermentasi sebesar 55,11\% lebih rendah dari pada bungkil kelapa yaitu sebesar $78,7 \%$, akan tetapi kandungan energi pada ransum keempat perlakuan masih berada dalam kisaran yang relatif sama. Hal inilah yang menyebabkan tingkat konsumsi pakan yang sama.

Selain itu tingkat konsumsi juga dipengaruhi oleh bermacam-macam faktor diantaranya yaitu dari hewan itu sendiri (bobot badan, jenis kelamin, umur, faktor genetik, dan tipe bangsa kelinci ), makanan yang diberikan, dan lingkungan tempat hewan tersebut dipelihara (McDonald et al., 2010). Faktor ternak dan kondisi lingkungan kandang pada saat penelitian relatif sama.

Tabel 1. Rataan Hasil Penelitian PBB (Pertambahan Bobot Badan) dan Konsumsi Pakan, Pakan Kelinci Lokal Jantan dengan Perlakuan Pakan Penggantian Bungkil Kelapa dengan Lumpur Sawit Fermentasi dalam Ransum

\begin{tabular}{ccc}
\hline \hline Perlakuan & PBB $(\mathrm{g} / \mathrm{e} / \mathrm{hr})$ & Konsumsi Pakan $(\mathrm{g} / \mathrm{e} / \mathrm{hr})$ \\
\hline P0 & $7,28 \pm 0,91$ & $40,11 \pm 0,88$ \\
P1 & $6,69 \pm 0,62$ & $36,64 \pm 0,52$ \\
P2 & $6,87 \pm 1,73$ & $37,21 \pm 0,81$ \\
P3 & $7,31 \pm 1,01$ & $42,36 \pm 0,34$ \\
\hline
\end{tabular}

Keterangan:

$\mathrm{P} 0=$ rumput lapang dan pakan konsentrat dengan kandungan bungkil kelapa $15 \%$ dan lumpur sawit fermentasi $0 \%$

P1 = rumput lapang dan pakan konsentrat dengan kandungan bungkil kelapa $10 \%$ dan lumpur sawit fermentasi $5 \%$

P2= rumput lapang dan pakan konsentrat dengan kandungan bungkil kelapa $5 \%$ dan lumpur sawit fermentasi $10 \%$

$\mathrm{P} 3=$ rumput lapang dan pakan konsentrat dengan kandungan bungkil kelapa $0 \%$ dan lumpur sawit fermentasi $15 \%$

\subsection{Pertambahan Bobot Badan}

Hasil analisis Anova pada penelitian menunjukkan bahwa perlakuan tidak berbeda nyata terhadap pertambahan bobot badan $(P>0,05)$. Rata-rata pertambahan bobot badan kelinci lokal jantan pada penelitian ini ditunjukkan pada tabel 1. Hal ini dikarenakan pemberian ransum pada setiap perlakuan memiliki kandungan protein yang masih sesuai standar persyaratan mutu konsentrat yang ditetapkan dalam NRC untuk kelinci pertumbuhan kandungan PK minimal 12-16\% sehingga menghasilkan pertambahan bobot badan yang tidak berbeda nyata (NRC, 1994).

Rataan nilai pertambahan berat badan kelinci yang diperoleh selama penelitian untuk masing-masing perlakuan P0, P1, P2 dan P3 berturut-turut yaitu 7,01; 5,99; 6,58; dan 7,01; g/ekor/hari. Pengaruh yang tidak nyata pada pertambahan berat badan ini disebabkan karena penggantian bungkil kelapa dengan lumpur sawit fermentasi dalam ransum akan menyebabkan ransum tersebut memiliki kandungan energi dan protein yang relatif sama, seperti yang dinyatakan oleh McNitt at el (2013) bahwa ransum dengan energi yang relatif sama menyebabkan tidak adanya perbedaan pada konsumsi sehingga berpengaruh terhadap pertambahan berat badan. 
Kebutuhan BK dan kebutuhan hidup pokok semakin meningkat seiring dengan meningkatnya bobot hidup ternak (Gidenne, 2010) sehingga jumlah nutrien yang tersisa untuk pertumbuhan pada kelinci penelitian relatif sama.

\subsection{Kecernaan Bahan Kering}

Hasil anova menyatakan bahwa rataan kecernaan bahan kering pakan kelinci lokal jantan selama penelitian berturut-turut dari nilai tertinggi sampai terendah P0, P1, P2 dan P3 adalah 53,31; 52,32; 51,71 dan 49,80 \%, seperti tertera pada Gambar 1. Hasil penelitian ini menunjukkan bahwa pengaruh perlakuan terhadap kecernaan bahan kering berbeda tidak nyata $(p>0,05)$. Artinya penggunaan LSF hingga level $15 \%$ tidak berpengaruh terhadap kecernaan bahan kering kelinci lokal jantan yang di pelihara di Kota Pontianak. Hal ini diduga disebabkan konsumsi bahan kering masingmasing perlakuan yang berbeda tidak nyata. Menurut Mcdonald et al (2010) bahwa tingginya kecernaan bahan kering dipengaruhi oleh jumlah pakan yang dikonsumsi. Faktor yang mempengaruhi tinggi rendahnya daya cerna bahan pakan adalah jenis ternak, jumlah pakan yang diberikan, komposisi pakan dan pengolahan pakan.

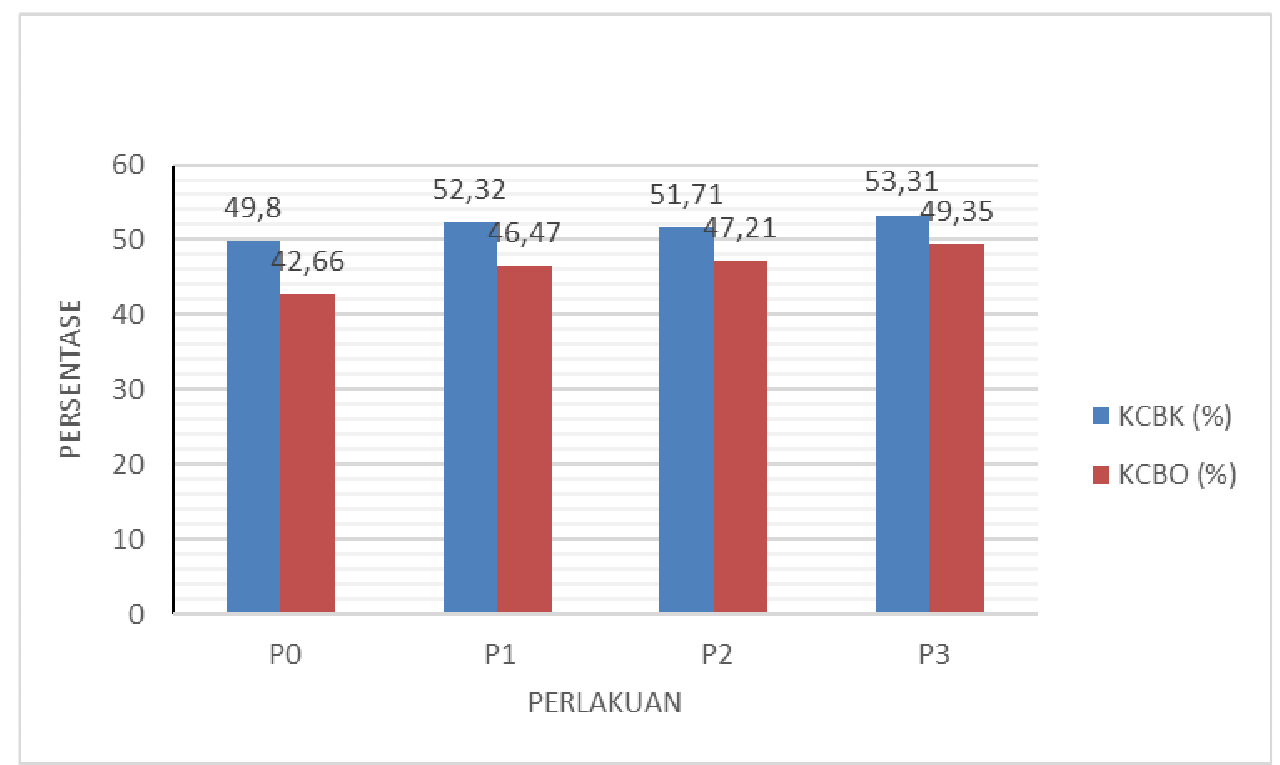

Gambar 1. Kecernaan Bahan Kering (KCBK) dan Kecernaan Bahan Organik (KCBO) pada kelinci lokal jantan selama penelitian (\%)

Kualitas suatu ransum ditentukan oleh tingkat kecernaannya, semakin tinggi kecernaan maka semakin baik kualitas ransum tersebut. Dedak padi fermentasi diduga mempunyai kandungan asam amino yang lebih baik dari konsentrat sehingga ransum yang diberi dedak padi fermentasi secara kuantitatif mampu meningkatkan kecernaan bahan kering suatu ransum. Winarno dan Fardiaz (1980) menjelaskan bahwa bahanbahan yang mengalami fermentasi mempunyai nilai gizi yang lebih tinggi dari bahan asalnya. Hal ini tidak hanya disebabkan mikrobia bersifat katabolik atau memecah 
komponen yang kompleks menjadi zat-zat yang sederhana sehingga lebih mudah dicerna, tetapi mikroba juga dapat mensintesis beberapa vitamin yang kompleks misalnya riboflavin, vitamin $B_{12}$ dan provitamin $A$

Peningkatan kecernaan menyebabkan saluran pencernaan lebih cepat kosong sehingga merangsang ternak untuk meningkatkan konsumsinya. Konsumsi bahan kering yang tidak berbeda nyata mengakibatkan kecernaan bahan kering yang juga tidak berbeda nyata (Soeparno, 2011). Tingkat konsumsi pakan berpengaruh terhadap kecernaan bahan kering dan bahan organik.

\subsection{Kecernaan Bahan Organik (KcBO)}

Hasil anova menyatakan bahwa rataan kecernaan bahan organik pakan kelinci lokal jantan selama penelitian berturut-turut dari nilai tertinggi sampai terendah P3, P2, P1 dan P0 adalah 49,35; 47,21; 46,47 dan 42,66 \%, seperti tertera pada Gambar 1 diatas. Hasil penelitian menunjukkan bahwa pengaruh perlakuan terhadap kecernaan bahan organik berbeda tidak nyata $(p>0,05)$, artinya penggunaan lumpur sawit fermentasi hingga level 15\% tidak berpengaruh terhadap kecernaan bahan organik kelinci lokal jantan yang dipergunakan selama penelitian. Hal ini diduga kecernaan bahan kering yang berbeda tidak nyata menyebabkan kecernaan bahan organik yang berbeda tidak nyata pula karena bahan organik merupakan komponen bahan kering. Di samping konsumsi bahan organik yang berbeda tidak nyata mempengaruhi kecernaan bahan organik. Menurut Tillman et al (1998) bahwa salah satu faktor yang mempengaruhi kecernaan adalah jumlah pakan yang dikonsumsi dan komposisi kimia pakan.

Kecernaan bahan organik yang berbeda tidak nyata ini diduga selama fermentasi proses penguraian zat-zat organik yang terkandung di dalam dedak padi menjadi komponen yang lebih sederhana berlangsung sempurna sehingga memudahkan pencernaan. Menurut Tazzoli et al., (2009) bahwa fermentasi dapat memecah bahanbahan yang sulit dicerna seperti selulosa, hemiselulosa dan polimer-polimernya menjadi bahan-bahan yang mudah dicerna seperti gula sederhana dan turunanturunannya. Nilai gizi suatu bahan pakan selain ditentukan oleh lengkapnya zta-zat yang terkandung di dalamnya juga sangat dipengaruhi oleh tinggi rendahnya daya cerna dan energi bahan pakan tersebut (de Blas et al., 2010).

Beberapa faktor yang mempengaruhi daya cerna suatu bahan pakan antara lain komposisi kimia bahan pakan, jumlah pakan yang diberikan, pengolahan bahan pakan dan individu (tenak) yang bersangkutan (Parakkasi, 1999). 


\section{Kesimpulan}

Berdasarkan hasil ANOVA dan pembahasan pada penelitian ini dapat disimpulkan bahwa penggunaan lumpur sawit fermentasi dalam ransum pada perlakuan P0 (0\%), P1(5\%), P2 (10\%) dan P3 (15\%) tidak berpengaruh nyata terhadap kecernaan kelinci lokal jantan.

\section{Daftar Pustaka}

Chen P, and Li PF. 2008. Effect of dietary fat addition on growth performance, nutrient digestion and caecum fermentation in 2-3 months old meat rabbits. Proceedings of the 9th World Rabbits Congress. Italy.

Damron WS. 2006. Introduction to Animal Science. 3rd Edition. New Jersey Pearson education. Upper Sanddle River.

de Blas, C. and J. Wiseman. 2010. Nutrition of the rabbit. 2nd Edition. CAB International. London

Direktorat Jenderal Perkebunan. 2012. Statistik Perkebunan Indonesia, Departemen Pertanian Jakarta.

Gidenne T, Carabano R, Garcia J, de Blas C. 2010. Fibre Digestion Nutrition of the Rabbit, 2 Edition. Wallingford. Editor : de Blas \& Wiseman. CABI Publishing

Hidayat, Soetrisno, E., Akbarillah,T. 2007. Produksi ternak Sapi Berbasis Hasil Ikutan Kebun Sawit Melalui Peningkatan Kualitas Pakan, manipulasi Ekosistem Mikrobia Rumen Dan Protein By Pass. Laporan Penelitian Hibah Bersaing . Lembaga Penelitian Universitas Bengkulu.

Lekito, M.N. 2002. Analisis kandungan nutrisi Lumpur minyak sawit (Palm Oil Sludge) asal pabrik pengolahan di Kecamatan Prafi Kabupaten Manokwari Propinsi Papua. Jurnal Peternakan dan Lingkungan, Vol.08 No.1. Februari 2002, hal. 59 -62.

Maksum AR, 2005. Pengaruh Penggantian Bungkil Kelapa Dengan Ampas Tahu Fermentasi Dalam Ransum Terhadap Performan Kelinci Lokal Jantan. Skripsi. Universitas Sebelas Maret. Surakarta.

Mattjik AA, Sumertajaya IM. 2002. Perancangan Percobaan dengan Aplikasi SAS dan Minitab. Jilid I. Edisi ke-2. Bogor: Institut Pertanian Bogor (IPB)-Press.

McDonald, P., Edwards, R., Greenhalgh, J. 2010. Animal Nutrition. $7^{\text {th }}$ Ed. New York.

McNitt. J. I, S. D. Lukefahr, P. R. Cheeke dan N. M. Patton. 2013. Rabbit production. Cabi. Wallingford.

National Research Council. 1994. Nutrient and Requirement of Rabbit Production. The Interstate Printers and Company Ltd. Ram Nagar. New Delhi.

Soeparno. 2011. Ilmu Nutrisi dan Gizi Daging. Gadjah Mada University. Press.Yogyakarta. 
Sunarwati.2001. Pengaruh Pemberian Pellet Ubi Jalar (Ipomea batatas (L) lam) Terhgadap Performans Kelinci Persilangan Lepas Sapih. Skripsi.Institut Pertanian Bogor. Bogor.

Sudaryanto B. 2007. Budidaya Ternak Kelinci di Perkotaan. Yogyakarta: Balai Pengkajian Teknologi Pertanian Yogyakarta.

Tazzoli M, Carraro L, Trocino A, Majolini D, Xiccato G. 2009. Replacing starch with digestible fibre in growing rabbit feeding. J Anim Sci. 8 suppl. 3:148- 250.

Tillman, A.D., H. Hartadi, S. Reksohadiprodjo, S. Prawirokusumo, dan S. Lebdosukojo, 1998. Ilmu Makanan Ternak Dasar. Cetakan ke-4. Gadjah Mada University Press, Yogyakarta. 